Folia Cardiologica 2017 tom 12 , nr 4, strony 422-430 DOI: 10.5603/FC.2017.0077 Copyright @ 2017 Via Medica ISSN 2353-7752

\title{
Niedokrwistość i niedobór żelaza u chorych z niewydolnością serca - postępowanie diagnostyczne i terapeutyczne
}

\author{
Anemia and iron deficiency in patients with heart failure \\ - diagnostic and therapeutic management
}

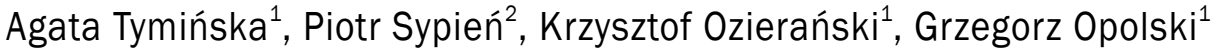 \\ ${ }^{1}$ I Katedra i Klinika Kardiologii Warszawskiego Uniwersytetu Medycznego \\ ${ }^{2}$ Studenckie Koło Naukowe przy I Katedrze i Klinice Kardiologii Warszawskiego Uniwersytetu Medycznego
}

\section{Streszczenie}

Przewlekła niewydolność serca (HF) jest narastającym problemem ochrony zdrowia w krajach wysoko rozwiniętych. W najnowszych wytycznych Europejskiego Towarzystwa Kardiologicznego (ESC) dotyczących postępowania w HF podkreślono potrzebę uwzględnienia czynników ryzyka i chorób towarzyszących, które nasilają objawy HF oraz niekorzystnie wpływają na rokowanie. W ostatnim czasie tematyka licznych badań obejmowała niedokrwistość i niedobór żelaza, które często są obserwowane u pacjentów z HF. Zgodnie z definicją niedokrwistość stwierdza się przy stężeniu hemoglobiny poniżej 13,0 g/dl u mężczyzn i 12,0 g/dl u kobiet. W przebiegu HF wiele czynników może prowadzić do rozwoju niedokrwistości, podczas gdy niedobór żelaza może występować niezależnie od obecności niedokrwistości, a także niezależnie pogarszać rokowanie pacjentów z HF. Według wytycznych ESC niedobór żelaza u pacjenta z HF stwierdza się przy stężeniu osoczowej ferrytyny poniżej $100 \mu \mathrm{g} / \mathrm{l}$ lub ferrytyny 100-299 $\mu \mathrm{g} / \mathrm{I}$ przy wysyceniu transferryny żelazem poniżej $20 \%$. W niniejszym artykule omówiono częstość i przyczyny występowania niedokrwistości, jej znaczenie prognostyczne, a także postępowanie diagnostyczne oraz możliwości terapeutyczne u pacjentów z HF. Obecnie dostępnych jest kilka form leczenia niedokrwistości. Jednak jedynym leczeniem o udowodnionej efektywności i bezpieczeństwie jest dożylna suplementacja żelaza u objawowych chorych z HF ze zredukowaną frakcją wyrzucania lewej komory przy towarzyszącym niedoborze żelaza.

Słowa kluczowe: niedokrwistość, niedobór żelaza, niewydolność serca, leczenie, diagnostyka, rokowanie

Folia Cardiologica 2017; 12, 4: 422-430

\section{Wstęp}

Niewydolność serca (HF, heart failure) to jednostka chorobowa o zróżnicowanej etiologii i patogenezie, która jest wiodącą przyczyną zachorowalności i umieralności osób dorosłych na świecie [1, 2]. Na podstawie wyników polskiej części rejestru HF Europejskiego Towarzystwa Kardiolo- gicznego (ESC, European Society of Cardiology) roczna śmiertelność pacjentów hospitalizowanych z powodu HF wynosi blisko 11\%, natomiast ryzyko zgonu lub powtórnej hospitalizacji z powodu HF w ciągu rocznej obserwacji ponad 55\% [3]. Przekłada się to również na bardzo wysokie koszty opieki zdrowotnej [4, 5]. Według analizy z 2012 roku Narodowy Fundusz Zdrowia (NFZ) sfinansował świadczenia

Adres do korespondencji: lek. Agata Tymińska, I Katedra i Klinika Kardiologii, Warszawski Uniwersytet Medyczny, Samodzielny Publiczny Centralny Szpital Kliniczny, ul. Banacha 1a, 02-097 Warszawa, e-mail: tyminska.agata@gmail.com 
zdrowotne w HF w wysokości ponad 672 milinów złotych, w tym większość stanowiły świadczenia szpitalne (94\%), a na opiekę ambulatoryjną przeznaczono zaledwie 2\% [5].

W ostatnich wytycznych ESC dotyczących postępowania w HF podkreślono potrzebę uwzględnienia czynników ryzyka i chorób towarzyszących, które nasilają objawy HF oraz niekorzystnie wpływają na rokowanie [1]. Wytyczne szczególnie podkreślają taką potrzebę u pacjentów z HF z zachowaną frakcją wyrzutową (HFpEF, heart failure with preserved ejection fraction) z uwagi na częstsze występowanie chorób towarzyszących oraz trudności z wyborem optymalnej terapii, wynikające z braku dowodów na poprawę przeżycia przy zastosowaniu standardowych form leczenia w tej populacji $[1,6]$.

W aktualnych wytycznych spośród istotnych czynników ryzyka wyróżniono niedokrwistość oraz niedobór żelaza, który także niezależnie od współwystępowania niedokrwistości pogarsza rokowanie pacjentów z HF [1]. Mnogość czynników ryzyka rozwoju i progresji HF wpływa na potrzebę ich identyfikacji i ciągłego udoskonalania kompleksowej terapii HF. W niniejszym artykule przedstawiono problematykę niedokrwistości oraz niedoboru żelaza w populacji pacjentów z HF, a także metody diagnostyczne oraz formy i skuteczność dostępnych terapii.

\section{Epidemiologia i definicje}

\section{Niedokrwistość\}}

Według definicji Światowej Organizacji Zdrowia (WHO, World Health Organization) niedokrwistość stwierdza się przy stężeniu hemoglobiny poniżej 13,0 g/dl u mężczyzn i 12,0 g/ /dl u kobiet (tab. 1). Częstość występowania niedokrwistości u chorych z HF waha się w zakresie 5-70\% w różnych badaniach (w zależności od użytej definicji niedokrwistości oraz charakterystyki klinicznej pacjentów włączonych do badania), a także wzrasta proporcjonalnie do wieku, nasilenia HF i chorób współtowarzyszących, ponadto częściej dotyka płeć żeńską [1, 7-10].

Należy podkreślić, że dane z randomizowanych badań klinicznych wykazują niższą częstość występowania niedo-

Tabela 1. Definicje niedokrwistości (wg World Health Organization) oraz niedoboru żelaza u chorych z niewydolnością serca (na podstawie [1])

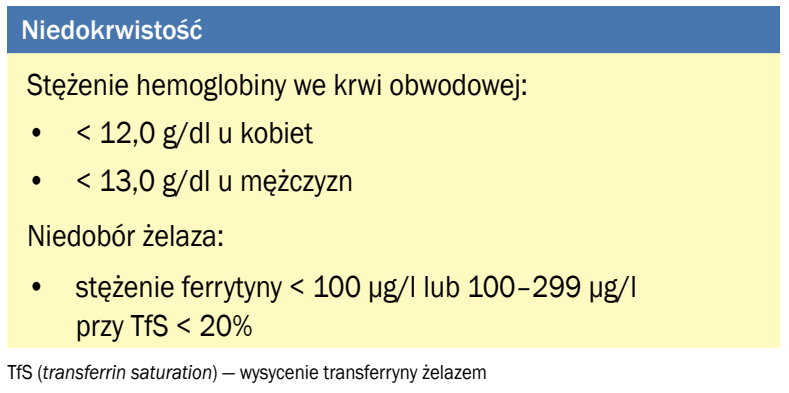

krwistości w populacji pacjentów z HF, niż obrazują to badania obserwacyjne. Jest to spowodowane włączaniem do badań klinicznych bardziej wyselekcjonowanych, młodszych pacjentów oraz wykluczaniem osób z ciężką niedokrwistością. Zgodnie z danymi płynącymi z polskiej części rejestru ESC-HF niedokrwistość występowała średnio u co trzeciego chorego z HF [11]. Jonsson i wsp. zaobserwowali także wyższe prawdopodobieństwo wystąpienia niedokrwistości u pacjentów będących w wyższej klasie czynnościowej według klasyfikacji New York Heart Association (NYHA) 61,9\% w stopniu III lub IV w porównaniu z 38,1\% pacjentów w klasie I lub II [12].

\section{Niedobór żelaza}

Należy podkreślić, że niedobór żelaza może występować niezależnie od obecności niedokrwistości lub prowadzić do jej powstania [13-15]. W kontekście układu sercowo-naczyniowego udowodniono, że niedobór żelaza może powodować dysfunkcję kardiomiocytów, również niezależnie od współwystępowania niedokrwistości [13]. W wieloośrodkowym badaniu nad populacją pacjentów z HF wykazano występowanie niedoboru żelaza u 58\% pacjentów, tymczasem niedokrwistość rozpoznano zaledwie u 35\% chorych [14]. Natomiast w międzynarodowym badaniu przeprowadzonym przez Klip i wsp., obejmującym 1506 chorych z przewlekłą HF, częstość występowania niedoboru żelaza wynosiła 50\%, w tym 45,6\% wśród pacjentów bez niedokrwistości [15].

Objawy niedoboru żelaza nie są specyficzne, dlatego jedynie ocena parametrów gospodarki żelaza pozwala na diagnozę niedoboru żelaza. Co więcej, niedokrwistość z niedoboru żelaza często może zostać nierozpoznana w rutynowym badaniu morfologicznym krwi. De Silva i wsp. wykazali występowanie obniżonego stężenia żelaza i ferrytyny u 43\% pacjentów z HF, natomiast u osób ze stwierdzoną niedokrwistością mikrocytową jedynie u 6\% [16]. Z tego względu ESC zaleca oznaczanie gospodarki żelazowej u każdego pacjenta z HF niezależnie od obecności cech niedokrwistości [1]. Według wytycznych ESC niedobór żelaza u pacjenta z HF stwierdza się przy stężeniu osoczowej ferrytyny poniżej $100 \mu \mathrm{g} / \mathrm{l}$ lub ferrytyny wynoszącej 100-299 $\mu \mathrm{g} / \mathrm{I}$ przy wysyceniu transferryny żelazem (TfS, transferrin saturation) poniżej 20\% (tab. 1) [1]. Należy podkreślić, że uznana przez wytyczne definicja niedoboru żelaza została użyta w większości badań klinicznych, w których podawano żelazo w formie dożylnej pacjentom z przewlekłą HF. Dotychczas brakuje potwierdzenia, czy powyższa definicja niedoboru żelaza znajduje również zastosowanie u pacjentów z ostrą HF.

\section{Etiologia niedokrwistości}

W przebiegu HF wiele czynników może prowadzić do rozwoju niedokrwistości, a główna przyczyna nierzadko pozostaje nieznana. Zaburzenia gospodarki żelazowej stanowią 


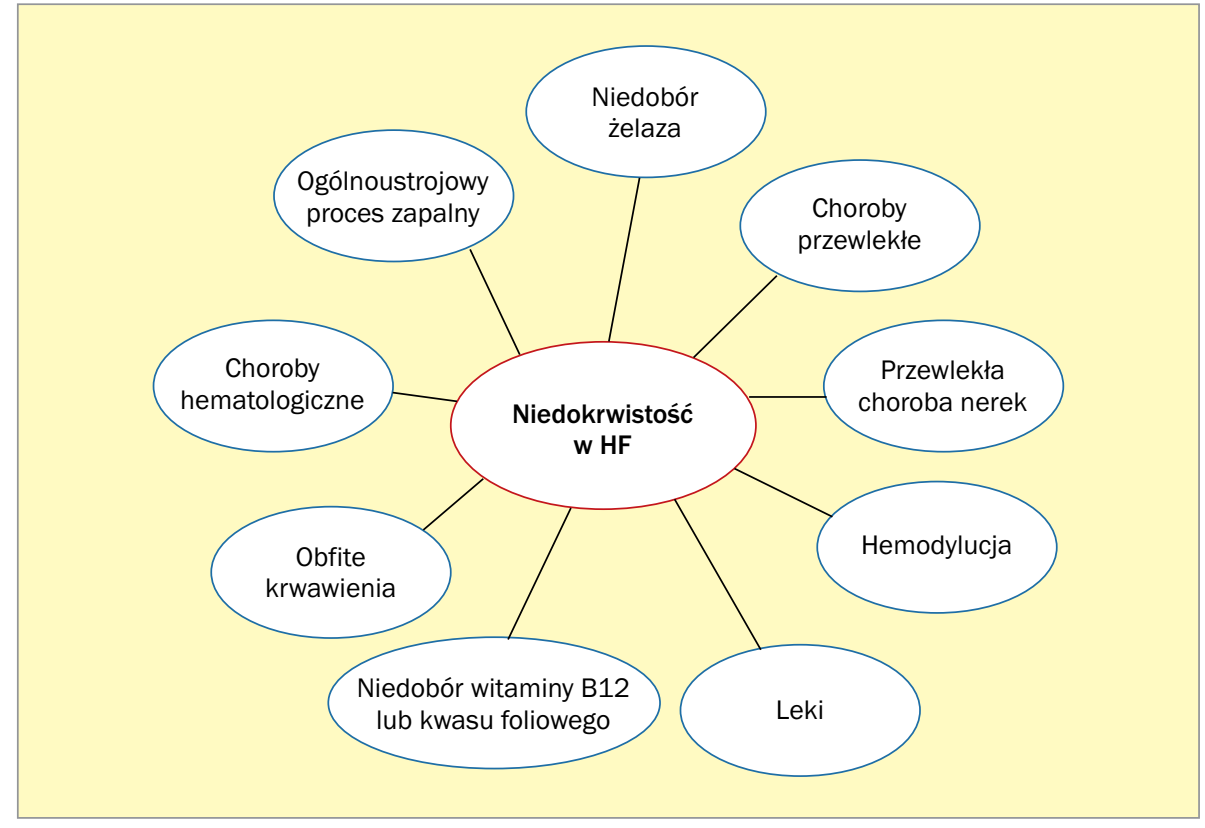

Rycina 1. Przyczyny niedokrwistości u chorych z niewydolnością serca (HF, heart failure)

jedną z głównych przyczyn niedokrwistości. Nanas i wsp. jako główne przyczyny niedokrwistości u pacjentów z HF wskazali: niedobór żelaza (73,0\%), niedokrwistość chorób przewlekłych $(18,9 \%)$, hemodylucję $(5,4 \%)$ oraz jatrogenna niedokrwistość $(2,7 \%)$ [17]. Występowanie niedokrwistości rzadziej wiąże się z niedoborem witaminy B12 i kwasu foliowego [17]. Ponadto inne potencjalne przyczyny niedokrwistości należy uwzględnić w diagnostyce (ryc. 1).

Czynnikiem predysponującym do wystąpienia niedokrwistości mogą być niedobory pokarmowe i kacheksja u pacjenta z HF. Obrzęk błony śluzowej w przewodzie pokarmowym u pacjentów z zastoinową HF wpływa na zaburzenie wchłaniania żelaza oraz innych elementów niezbędnych w erytropoezie (witamina B12, kwas foliowy). U chorych z HF wykazano zmniejszoną perfuzję krwi w przewodzie pokarmowym nawet o 30-43\% [18].

Jednym z najważniejszych czynników powodujących niedokrwistość jest występowanie niewydolności nerek. Spadek filtracji kłębuszkowej przyczynia się do zwiększenia retencji sodu, wzrostu objętości płynów w organizmie i spadku hematokrytu. Następuje również spadek produkcji erytropoetyny przez nerki [19]. W HF produkcja erytropoetyny wzrasta wraz ze stopniem zaawansowania niewydolności serca według NYHA, jednak niewystarczająco w stosunku do zapotrzebowania i zaawansowania niedokrwistości [19]. Współistniejąca cukrzyca może nasilić ten efekt - u osób chorych na cukrzycę stężenie hemoglobiny jest średnio $01 \mathrm{~g} / \mathrm{dl}$ niższe niezależnie od stopnia dysfunkcji nerek [20].

Niedokrwistość chorób przewlekłych wiąże się ze zmienionym metabolizmem i produkcją wielu cytokin prozapalnych, które wpływają na spadek produkcji krwinek czerwonych, między innymi poprzez zmniejszenie aktywności erytropoetyny. Współistnienie procesu nowotworowego z HF zwiększa również prawdopodobieństwo rozwoju niedokrwistości ze względu na produkowane cytokiny [21]. Wzrost stężenia interferonu-y, lipopolisacharydu oraz TNF $\alpha$ (TNF $\alpha$, tumor necrosis factor $\alpha$ ) przyczynia się także do magazynowania żelaza przez makrofagi oraz zmniejszenia jego wchłaniania w przewodzie pokarmowym [21].

Ponadto farmakoterapia stosowana u pacjentów z HF ma wpływ na rozwój niedokrwistości. Stosowanie inhibitorów konwertazy angiotensyny (ACE, angiotensin-converting enzyme) oraz antagonistów receptora angiotensyny (ARB, angiotensin receptor blocker) wpływa na ograniczenie produkcji i aktywności angiotensyny. Enzym ten stymuluje erytropoetynę, a jego zmniejszenie przyczynia się do spadku erytropoezy $[8,22]$. Stosowanie leków przeciwpłytkowych oraz przeciwkrzepliwych poprzez zwiększone ryzyko wystąpienia krwawienia może się wiązać ze zmniejszonym stężeniem hemoglobiny we krwi $[8,22]$.

U pacjentów dodatkowo obciążonych wywiadem, między innymi przebytego zawału serca lub zabiegu pomostowania aortalno-wieńcowego, występuje większe prawdopodobieństwo rozpoznania niedokrwistości [8]. Stosowanie hemodylucji podczas zabiegów może się także przyczynić do wystąpienia niedokrwistości [8].

\section{Czynniki ryzyka niedokrwistości}

Ważnym aspektem w postępowaniu diagnostycznym u pacjenta z HF jest identyfikacja czynników ryzyka wystąpienia niedokrwistości (tab. 2). W przypadku ich stwierdzenia 
Tabela 2. Czynniki ryzyka wystąpienia niedokrwistości u chorych z niewydolnością serca (HF, heart failure)

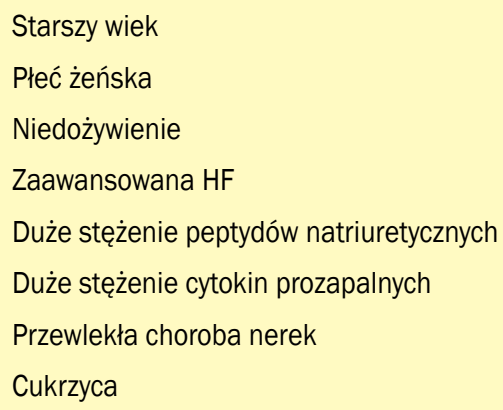

Farmakoterapia niewydolności serca (inhibitory ACE/ARB, leki moczopędne, przeciwpłytkowe, przeciwkrzepliwe)

Zaburzenia wchłaniania

ACE (angiotensin-converting-enzyme) - konwertaza angiotensyny; ARB (angiotensin receptor blocker) - antagonista receptora angiotensyny

jest wymagana wzmożona kontrola stężenia hemoglobiny. Czynniki ryzyka sprzyjające wystąpieniu niedoboru żelaza są zbliżone do czynników ryzyka niedokrwistości.

\section{Diagnostyka}

Niedokrwistość związana z niedoborem żelaza wiąże się najczęściej z pojawieniem się małych erytrocytów niedobarwliwych we krwi obwodowej, co ma swoje odzwierciedlenie w obniżeniu średniego stężenia hemoglobiny w krwince (MCHC, mean corpuscular hemoglobin concentration), oraz obniżeniem objętości erytrocytów (MCV, mean corpuscular volume). Z kolei niedokrwistość wywołana zaburzeniem erytropoezy w szpiku w badaniach laboratoryjnych objawia się jako zmniejszenie liczby krwinek czerwonych z prawidłową MCV. Zaburzenia wchłaniania witaminy $\mathrm{B}_{12}$ i kwasu foliowego przyczyniają się do pojawienia się nadbarwliwych, olbrzymich komórek, z podwyższonym MCV, natomiast przewlekłym krwawieniom towarzyszy wzrost odsetka retykulocytów [23, 24].

W ramach oceny gospodarki żelaza nie zaleca się oznaczania samego stężenia żelaza we krwi obwodowej. Uważa się, że w praktyce ferrytyna i TfS oznaczane w surowicy są lepszymi parametrami odzwierciedlającym ilość żelaza w organizmie, która jest dostępna dla potrzeb metabolizmu komórek (tab. 3).

Wyróżnia się bezwzględny i czynnościowy niedobór żelaza. Bezwzględny niedobór żelaza występuje przy zużyciu magazynów żelaza w organizmie. Jednakże należy pamiętać, że ferrytyna jest białkiem ostrej fazy i jej stężenie wzrasta podczas toczącego się procesu zapalnego. Dlatego, mimo że w populacji ogólnej bezwzględny niedobór żelaza występuje przy stężeniu ferrytyny poniżej 30 mg/l, w przypadku chorób przewlekłych, w tym HF, przyjęto stężenie poniżej $100 \mu \mathrm{g} / \mathrm{l}$. Stężenie transferyny w surowicy w mniejszym stopniu jest zależne od zmian metabolizmu żelaza. Zmniejszenie nasycenia żelazem transferyny wskazuje na brak dostarczania żelaza do erytroblastów i innych wymagających żelaza komórek. Wartość TfS mniejsza niż 20\% przy stężeniu ferrytyny we krwi obwodowej wynoszącym

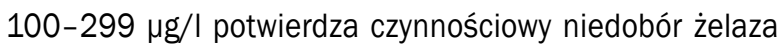
$[13,25]$.

Niewykorzystywaną ze względu na inwazyjność i ograniczony dostęp metodą w ocenie gospodarki żelazowej jest biopsja aspiracyjna szpiku kostnego.

\section{Następstwa niedokrwistości i niedoboru żelaza}

Przewlekła niedokrwistość prowadzi do zmniejszenia obwodowego oporu naczyniowego $[25,26]$ i spadku ciśnienia krwi, które jest kompensowane przez aktywację układu współczulnego oraz układu renina-angiotensyna-aldosteron. W konsekwencji dochodzi do zatrzymywania wody i sodu w organizmie. Wzrastająca objętość osocza oraz przestrzeni pozakomórkowej prowadzi do nasilenia objawów HF $[25,26]$. Ponadto spadek hemoglobiny powoduje zmniejszenie ilości dostarczanego tlenu do komórek [27, 28]. Utrzymująca się niedokrwistość prowadzi do niekorzystnej przebudowy mięśnia sercowego, doprowadzając do jego zapalenia i przerostu, a także poszerzenia jam serca. Ponadto niedokrwistość jest silnie związana z dysfunkcją rozkurczową mięśnia sercowego (ryc. 2) [25, 27].

Tabela 3. Parametry laboratoryjne niedokrwistości

\begin{tabular}{|c|c|c|c|c|c|}
\hline Typ niedokrwistości & $\begin{array}{l}\text { Rozpuszczalny recep- } \\
\text { tor dla transferyny }\end{array}$ & $\begin{array}{c}\text { Saturacja trans- } \\
\text { feryny }\end{array}$ & $\begin{array}{l}\text { Całkowita zdol- } \\
\text { ność wiązania } \\
\text { żelaza (TIBC) }\end{array}$ & Ferrytyna & Żelazo \\
\hline Niedobór żelaza & $\uparrow$ & $\downarrow$ & $\uparrow$ & $\downarrow$ & $\downarrow$ \\
\hline $\begin{array}{l}\text { Niedokrwistość chorób } \\
\text { przewlekłych }\end{array}$ & $\rightleftharpoons \operatorname{lub} \uparrow$ & $\downarrow$ & $\downarrow$ & $\rightleftharpoons \operatorname{lub} \uparrow$ & $\downarrow$ \\
\hline $\begin{array}{l}\text { Niedobór żelaza zwią- } \\
\text { zany z niewydolnością } \\
\text { serca }\end{array}$ & $\uparrow$ & $\downarrow$ & $\rightleftharpoons \operatorname{lub} \uparrow$ & $\uparrow$ & $\downarrow$ \\
\hline
\end{tabular}




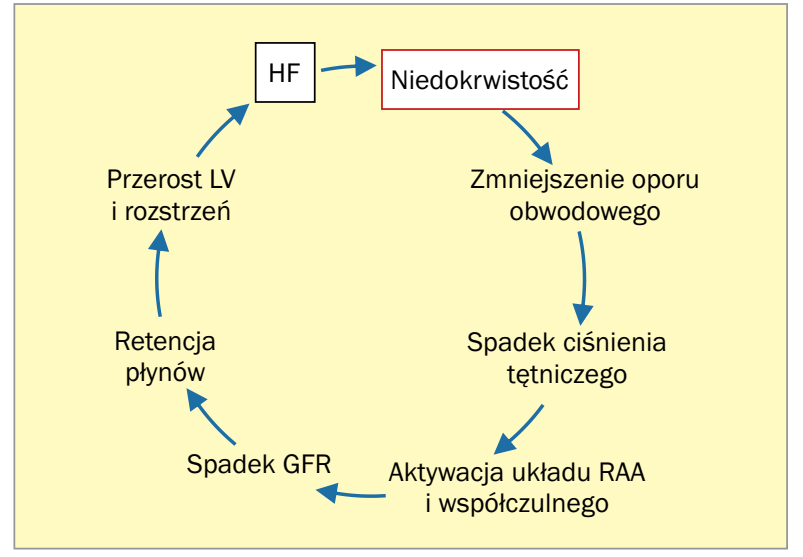

Rycina 2. Konsekwencje niedokrwistości; HF (heart failure) niewydolność serca; RAA (renin-angiotensin-aldosterone) - renina-angiotensyna-aldosteron; GFR (glomerular filtration rate) - współczynnik przesączania kłębuszkowego; LV (left ventricle) - lewa komora (opracowano i zmodyfikowano na podstawie Palazzuoli A et al. Folia Cardiol. Excerpta 2008; 3(5): 264-270)

Chociaż niedobór żelaza jest obecnie uznawany za ważną chorobę współwystępującą z HF, często jest ignorowany lub badany tylko w kontekście niedokrwistości. Żelazo jest kofaktorem wielu enzymów regulujących ważne procesy metaboliczne. Trzy białka (transferyna, receptor transferyny i ferrytyna) odgrywają kluczową rolę w przechowywaniu i transporcie żelaza w organizmie. Transferyna transportuje żelazo w osoczu i płynach pozakomórkowych. Liczba receptorów transferryny, obecnych na błonach komórkowych, koreluje z zawartością żelaza w komórkach. Ich rolą jest wyłapywanie i internalizacja transferryny w celu pozyskania żelaza przez komórki docelowe, podczas gdy rolą ferrytyny jest przechowywanie żelaza w tkankach (ryc. 3) [28, 29].

Innymi białkami odgrywającymi rolę w regulacji ogólnoustrojowej gospodarki żelaza są hepcydyna i ferroportyna.
Dzięki nim możliwa jest regulacja absorpcji żelaza przez komórki jelitowe lub makrofagi układu siateczkowo-śródbłonkowego [28, 29].

\section{Rokowanie}

Niedokrwistość jest częsta u pacjentów hospitalizowanych z powodu HF oraz jest silnie związana z niekorzystnym rokowaniem. W badaniach zaobserwowano korelację pomiędzy niskim stężeniem hemoglobiny a cięższym przebiegiem choroby, zwiększonym indeksem masy lewej komory, ryzykiem ponownej hospitalizacji i śmiertelnością [1, 30, 31]. Felker i wsp. wykazali, że spadek stężenia hemoglobiny $01 \mathrm{~g} / \mathrm{dl}$ powoduje 12-procentowy wzrost prawdopodobieństwa zgonu lub hospitalizacji w ciągu 60 dni [32]. Mimo że niedokrwistość znacząco częściej występuje wśród starszej populacji, niedokrwistość u osób poniżej 76. roku życia w większym stopniu wpływa na występowanie objawów HF w porównaniu z osobami starszymi [12].

Intrygujące są wyniki niedawno opublikowanej analizy danych pochodzących z polskiej części rejestru ESC-HF, która wykazała, że u pacjentów z HF łagodna lub umiarkowana niedokrwistość była markerem starszego wieku, gorszego stanu ogólnego, częstszego występowania chorób towarzyszących oraz rzadszego stosowania terapii modyfikującej przebieg HF, natomiast jednocześnie sama nie była bezpośrednią przyczyną występowania klinicznych punktów końcowych, takich jak zgon lub hospitalizacja z powodu zaostrzenia HF [11]. Podążając za autorami, wydaje się, że celem samym w sobie nie jest korekcja stężenia hemoglobiny. Stwierdzenie niedokrwistości natomiast powinno prowadzić do bliższej opieki nad danym pacjentem oraz wiąże się z koniecznością oceny gospodarki żelazowej.

Zaburzenia gospodarki żelazowej stanowią negatywny czynnik rokowniczy progresji HF (ryc. 3) [1, 13, 14]. W kilku

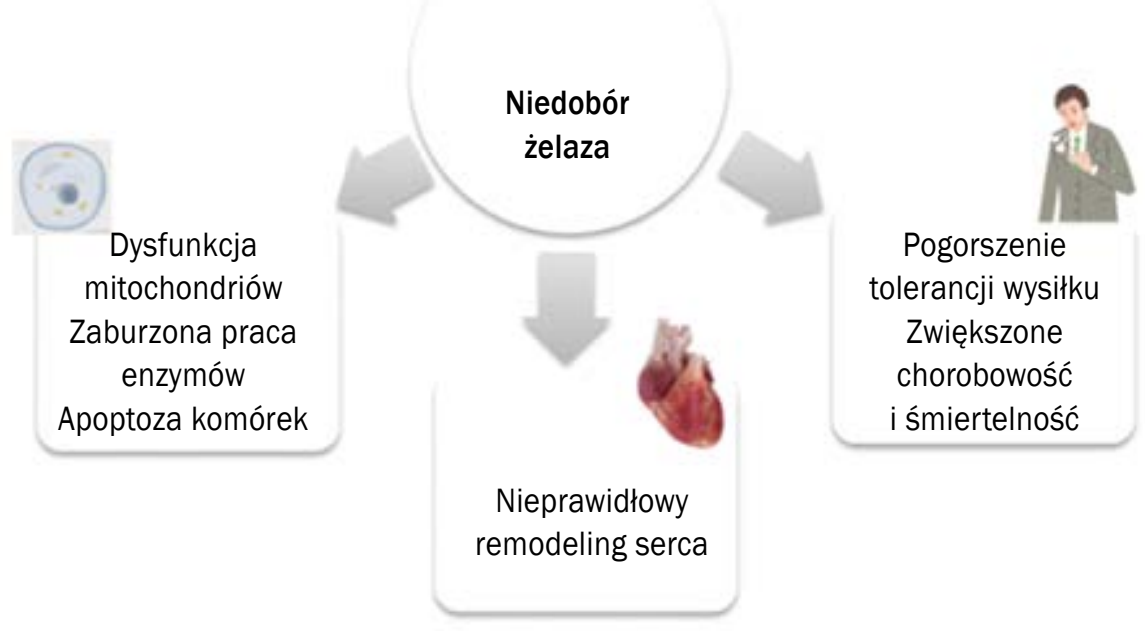

Rycina 3. Konsekwencje niedoboru żelaza (opracowano i zmodyfikowano na podstawie [24]) 
badaniach potwierdzono związek przyczynowy między niedoborem żelaza (z niedokrwistością i bez niedokrwistości) a wpływem na tolerancję wysiłku i jakość życia pacjentów z HF [33-35]. Ponadto Klip i wsp. wykazali u chorych z przewlekłą HF, że niedobór żelaza (ale nie niedokrwistość) był niezależnym czynnikiem śmiertelności oraz był związany z nasileniem choroby (wg skali NYHA) i wzrostem stężenia $\mathrm{N}$-końcowego fragmentu propeptydu natriuretycznego typu B (NT-proBNP, N-terminal B-type natriuretic propeptide) [15]. Ponadto w obserwacjach Maedera i wsp. wykazano spadek stężenia żelaza w mięśniu sercowym u pacjentów z HF, co może być dowodem potwierdzającym niekorzystny wpływ niedoboru żelaza na spadek kurczliwości mięśnia sercowego i progresję HF [36].

\section{Leczenie}

Obecnie dostępnych jest kilka form leczenia niedokrwistości - od standardowej doustnej suplementacji żelaza, witaminy $\mathrm{B}_{12}$ czy przetoczeń krwi oraz suplementacji erytropoetyny przy zaawansowanej niedokrwistości, możliwe jest także prowadzenie dożylnej terapii żelazem. Jednak, jak do tej pory, w żadnym z badań nie wykazano przekonujących wyników dotyczących poprawy przeżywalności pacjentów z niedokrwistością i towarzyszącą HF [1, 33-35], natomiast istnieją dowody na korzyści ze stosowania terapii żelazem w kontekście poprawy objawów i jakości życia u pacjentów z niedoborem żelaza, niezależnie od występowania niedokrwistości [1, 33-35].

Pomimo wiedzy na temat związku niedokrwistości z gorszym rokowaniem pacjentów z HF, wciąż nie ustalono konkretnej strategii leczenia. Wybór odpowiedniej strategii wyrównania niedoboru żelaza u chorych z HF wiąże się z koniecznością indywidualnego podejścia do pacjenta. Złożony mechanizm powstawania niedokrwistości oraz współwystępowanie innych chorób przewlekłych stanowią istotny problem kliniczny.

Transfuzja krwi to najszybsza metoda korekcji niedokrwistości. Jest szczególnie przydatna w zaawansowanych stadiach niedoboru. Należy rozważyć przetoczenie krwi, gdy stężenie hemoglobiny wynosi poniżej $8 \mathrm{~g} / \mathrm{dl}$, chociaż niektórzy pacjenci ze względu na całokształt obrazu klinicznego mogą wymagać transfuzji już przy wyższych stężeniach hemoglobiny. Jednakże ze względu na duże ryzyko działań niepożądanych oraz krótkotrwały efekt terapeutyczny nie zaleca się rutynowego stosowania transfuzji u pacjentów z niedokrwistością [7, 37].

Doustna suplementacja żelaza to powszechna i tania forma leczenia niedoborów żelaza, jednak według najnowszych wyników nie przynosi oczekiwanych efektów leczenia u pacjentów z HF [29]. Korekcja stężenia żelaza podczas doustnej suplementacji wiąże się z długotrwałym procesem leczniczym. Wynika to z zaburzonej absorpcji żelaza w prze- biegu HF, czego skutkiem jest niedostateczna podaż żelaza w stosunku do zapotrzebowania w procesie erytropoezy. Ponadto, terapia żelazem per os jest kontrowersyjna również ze względu na promowanie rozwoju mikroorganizmów i komórek nowotworowych przy współistniejących infekcjach i chorobach rozrostowych [7, 29, 35].

W badaniu IRONOUT HF stosowanie $300 \mathrm{mg} / \mathrm{d}$. doustnej suplementacji kompleksu polisacharydowego żelaza względem placebo nie wpłynęło na poprawę tolerancji wysiłku fizycznego w grupie pacjentów z HF [29]. Badanie obejmowało 225 pacjentów z HF w II-IV klasie według NYHA, z obniżoną frakcją wyrzutową (HFrEF, heart failure with reduced ejection fraction) poniżej $40 \%$ oraz obniżonymi zasobami ustrojowymi żelaza. Autorzy badania podkreślają, że doustna suplementacja żelaza w grupie pacjentów z HFrEF nie jest uzasadniona, głównie tłumacząc to skromną przyswajalnością doustnych form żelaza. Ponadto, suplementacja nie powinna być zalecana osobom z już stwierdzonym upośledzonym wchłanianiem lub innymi dolegliwościami ze strony układu pokarmowego [35].

Dożylna podaż żelaza stanowi skuteczną alternatywę do leczenia doustnego. Według aktualnych wytycznych ESC, należy ją rozważyć jako podstawową metodę korekcji niedoboru żelaza u wszystkich objawowych pacjentów z HFrEF (klasa Ila, poziom A) [1]. Pozwala uniknąć problemów związanych z biodostępnością żelaza podawanego doustnie w chorobach przewlekłych oraz ogranicza ryzyko wystąpienia działań niepożądanych związanych z doustnym stosowaniem preparatów. W badaniu FAIR-HF oceniano wpływ dożylnej suplementacji kompleksu karboksymaltozy żelazowej względem standardowej terapii HF bez suplementacji żelaza na poprawę tolerancji wysiłku fizycznego pacjentów z HF [34]. Do badania włączono pacjentów z HF w II/III klasie według NYHA, ze zredukowaną frakcją wyrzutową, niedokrwistością i niedoborem żelaza (wg definicji przyjętej w wytycznych). Terapia wpłynęła na poprawę objawów według klasy czynnościowej NYHA, subiektywnej oceny stanu zdrowia pacjenta oraz wydłużyła dystans w teście 6-minutowego marszu po 24 tygodniach obserwacji [34]. Ponadto na podstawie wyników badania CONFIRM-HF można stwierdzić, że terapia dożylnymi preparatami żelaza wiąże się ze znaczną redukcją ponownych hospitalizacji z powodu HF [35]. Pozwala to wnioskować, że suplementacja preparatów żelaza u pacjentów z przewlekłą HF oraz towarzyszącym jego niedoborem ma uzasadnienie jedynie drogą dożylną, mimo że jest to dużo droższa forma terapii.

Istnieją doniesienia, że długotrwała terapia żelazem wiąże się ze zwiększonym stężeniem wolnych rodników tlenowych i przewlekłą aktywacją układu odpornościowego, która może doprowadzić do uszkodzenia tkanek i stanowi czynnik ryzyka wystąpienia incydentów sercowo-naczyniowych [38]. Dalsze badania wykazały jednak 
podobną częstość działań niepożądanych w populacjach pacjentów z HF poddawanych leczeniu w porównaniu z grupami kontrolnymi [38]. Stosowanie żelaza dożylnie rzadko jest powiązane z ryzykiem wystąpienia reakcji uczuleniowej. Dotyczy ono szczególnie stosowania preparatów zawierających małocząsteczkowy dekstran [38]. Leczenie powinno obejmować pacjentów z obniżonym stężeniem żelaza niezależnie od występowania objawów klinicznych czy laboratoryjnych niedokrwistości. Biorąc pod uwagę korzyści wynikające z leczenia oraz możliwe działania niepożądane związane z suplementacją żelaza, należy dokładnie określić grupę pacjentów, dla których ta metoda leczenia przynosi najwięcej korzyści. Wydaje się słuszne, aby nie stosować suplementacji żelaza u pacjentów z chorobami przewlekłymi przy prawidłowym stężeniu ferrytyny.

Terapia za pomocą preparatów stymulujących erytropoeze (ESA, erythropoiesis-stimulating agent) znalazła zastosowanie w wyrównaniu niedoboru żelaza u pacjentów z zaawansowaną przewlekłą chorobą nerek. W badaniach obejmujących pacjentów z HF dostrzeżono nieadekwatny wzrost erytropoezy w stosunku do zaawansowania objawów według skali NYHA, co uzasadniało możliwość zastosowania czynników stymulujących erytropoezę w leczeniu niedokrwistości towarzyszącej dysfunkcji układu sercowo-na- czyniowego [39]. W metaanalizie oceniającej skuteczność terapii za pomocą ESA (z darbepoetyną lub erytropoetyną) $w$ łagodnej lub umiarkowanej niedokrwistości u pacjentów z przewlekłą HFrEF leczenie nie zmniejszyło całkowitej śmiertelności i ponownej hospitalizacji, ale wiązało się z większym ryzykiem zdarzeń zakrzepowo-zatorowych i z tego powodu nie jest zalecane [39].

\section{Podsumowanie}

Niedokrwistość i niedobór żelaza stosunkowo często występują u chorych z HF, z jednej strony nasilając objawy $\mathrm{HF}$, a z drugiej niekorzystnie wpływając na rokowanie. Chociaż dotychczas tradycyjnie postrzegano niedobór żelaza jedynie jako ważny czynnik etiologiczny niedokrwistości u chorych z HF, dane z ostatnich lat pokazują, że również niedobór żelaza bez towarzyszącej niedokrwistości stanowi częsty problem o istotnych negatywnych konsekwencjach dla chorych z HF. Według najnowszych wytycznych ESC należy poszukiwać niedokrwistości oraz niedoboru żelaza niezależnie od stężenia hemoglobiny u wszystkich pacjentów z HF. Jedynym leczeniem o udowodnionej efektywności i bezpieczeństwie jest dożylna suplementacja żelaza u objawowych chorych z HFrEF i z towarzyszącym niedoborem żelaza.

\section{Abstract}

Chronic heart failure (HF) is a growing problem of highly developed countries. The latest guidelines of the European Society of Cardiology (ESC) on HF have stressed the need for diagnosis and treatment of risk factors and comorbidities that aggravate HF course and affect prognosis. Recently, the subject of numerous studies has included anemia and iron deficiency, which are highly prevalent in patients with HF. By definition, anemia is diagnosed at hemoglobin below $13.0 \mathrm{~g} / \mathrm{dL}$ in men and $12.0 \mathrm{~g} / \mathrm{dL}$ in women. In the course of HF many factors can lead to the development of anemia. While iron deficiency may occur independently of the presence of anemia, and independently may deteriorate the prognosis of HF patients. According to the ESC guidelines, iron deficiency in patients with HF is reported with serum ferritin below $100 \mu \mathrm{g} / \mathrm{L}$ or ferritin 100-299 $\mu \mathrm{g} / \mathrm{L}$ with iron transferrin saturation below $20 \%$. This article discusses the incidence of anemia, causes of its occurrence in HF, the importance of prognosis, as well as diagnostic and therapeutic options. Currently there are several forms of treatment for anemia. However, the only treatment with proven efficacy and safety is intravenous iron supplementation in symptomatic HF patients with reduced left ventricular ejection fraction associated with iron deficiency.

Key words: anemia, iron deficiency, heart failure, treatment, diagnosis, prognosis

Folia Cardiologica 2017; 12, 4: 422-430 


\section{Piśmiennictwo}

1. Ponikowski P, Voors AA, Anker SD, et al. Authors/Task Force Members, Document Reviewers, Authors/Task Force Members. 2016 ESC Guidelines for the diagnosis and treatment of acute and chronic heart failure: The Task Force for the diagnosis and treatment of acute and chronic heart failure of the European Society of Cardiology (ESC) Developed with the special contribution of the Heart Failure Association (HFA) of the ESC. Eur Heart J. 2016; 37(27): 2129-2200, doi: 10.1093/eurheartj/ehw128, indexed in Pubmed: 27206819.

2. Cleland JG, Khand A, Clark A. The heart failure epidemic: exactly how big is it? Eur Heart J. 2001; 22(8): 623-626, doi: 10.1053/ /euhj.2000.2493, indexed in Pubmed: 11286518.

3. Balsam P, Tymińska A, Kapłon-Cieślicka A, et al. Predictors of oneyear outcome in patients hospitalised for heart failure: results from the Polish part of the Heart Failure Pilot Survey of the European Society of Cardiology. Kardiol Pol. 2016; 74(1): 9-17, doi: 10.5603/ /KP.a2015.0112, indexed in Pubmed: 26101021.

4. Czech M, Opolski G, Zdrojewski T, et al. The costs of heart failure in Poland from the public payer's perspective. Polish programme assessing diagnostic procedures, treatment and costs in patients with heart failure in randomly selected outpatient clinics and hospitals at different levels of care: POLKARD. Kardiol Pol. 2013; 71(3): 224-232, doi: 10.5603/KP.2013.0032, indexed in Pubmed: 23575775.

5. Gierczyński J, Gryglewicz J, Karczewicz E. Niewydolność serca - analiza kosztów ekonomicznych i społecznych. Uczelnia Łazarskiego, 2013.

6. Kapłon-Cieślicka A, Tymińska A, Peller M, et al. Diagnosis, Clinical Course, and 1-Year Outcome in Patients Hospitalized for Heart Failure With Preserved Ejection Fraction (from the Polish Cohort of the European Society of Cardiology Heart Failure Long-Term Registry). Am J Cardiol. 2016; 118(4): 535-542, doi: 10.1016/j.amjcard.2016.05.046, indexed in Pubmed: 27374606.

7. Anand IS. Anemia and chronic heart failure implications and treatment options. J Am Coll Cardiol. 2008; 52(7): 501-511, doi: 10.1016/j. jacc.2008.04.044, indexed in Pubmed: 18687241.

8. Mentz RJ, Greene SJ, Ambrosy AP, et al. Clinical profile and prognostic value of anemia at the time of admission and discharge among patients hospitalized for heart failure with reduced ejection fraction: findings from the EVEREST trial. Circ Heart Fail. 2014; 7(3): 401-408, doi: 10.1161/CIRCHEARTFAILURE.113.000840, indexed in Pubmed: 24737459.

9. Young JB, Abraham WT, Albert NM, et al. OPTIMIZE-HF Investigators and Coordinators. Relation of low hemoglobin and anemia to morbidity and mortality in patients hospitalized with heart failure (insight from the OPTIMIZE-HF registry). Am J Cardiol. 2008; 101(2): 223-230, doi: 10.1016/j.amjcard.2007.07.067, indexed in Pubmed: 18178411.

10. Kajimoto K, Sato N, Takano T, et al. investigators of the Acute Decompensated Heart Failure Syndromes (ATTEND) registry, investigators of the Acute Decompensated Heart Failure Syndromes (ATTEND) registry. Association between anemia, clinical features and outcome in patients hospitalized for acute heart failure syndromes. Eur Heart J Acute Cardiovasc Care. 2015; 4(6): 568-576, doi: 10.1177/2048872614554199, indexed in Pubmed: 25315117.

11. Tymińska A, Kapłon-Cieślicka A, Ozierański K, et al. Anemia at Hospital Admission and Its Relation to Outcomes in Patients With Heart Failure (from the Polish Cohort of 2 European Society of Cardiology Heart Failure Registries). Am J Cardiol. 2017; 119(12): 2021-2029, doi: 10.1016/j.amjcard.2017.03.035, indexed in Pubmed: 28434647.
12. Jonsson A, Hallberg AC, Edner M, et al. A comprehensive assessment of the association between anemia, clinical covariates and outcomes in a population-wide heart failure registry. Int J Cardiol. 2016; 211: 124-131, doi: 10.1016/j.jicard.2016.02.144, indexed in Pubmed: 26999301.

13. Jankowska EA, von Haehling S, Anker SD, et al. Iron deficiency and heart failure: diagnostic dilemmas and therapeutic perspectives. Eur Heart J. 2013; 34(11): 816-829, doi: 10.1093/eurheartj/ehs224, indexed in Pubmed: 23100285.

14. Enjuanes C, Klip IT, Bruguera J, et al. Iron deficiency and health-related quality of life in chronic heart failure: results from a multicenter European study. Int J Cardiol. 2014; 174(2): 268-275, doi: 10.1016/j. ijcard.2014.03.169, indexed in Pubmed: 24768464.

15. Klip IT, Comin-Colet J, Voors AA, et al. Iron deficiency in chronic heart failure: an international pooled analysis. Am Heart J. 2013; 165(4): 575-582.e3, doi: 10.1016/j.ahj.2013.01.017, indexed in Pubmed: 23537975.

16. de Silva R, Rigby AS, Witte KKA, et al. Anemia, renal dysfunction, and their interaction in patients with chronic heart failure. Am J Cardiol. 2006; 98(3): 391-398, doi: 10.1016/j.amjcard.2006.01.107, indexed in Pubmed: 16860030.

17. Nanas JN, Matsouka C, Karageorgopoulos D, et al. Etiology of anemia in patients with advanced heart failure. J Am Coll Cardiol. 2006; 48(12): 2485-2489, doi: 10.1016/j.jacc.2006.08.034, indexed in Pubmed: 17174186.

18. Witte KKA, Desilva R, Chattopadhyay $S$, et al. Are hematinic deficiencies the cause of anemia in chronic heart failure? Am Heart J. 2004; 147(5): 924-930, doi: 10.1016/j.ahj.2003.11.007, indexed in Pubmed: 15131553.

19. Macdougall IC, Canaud B, de Francisco ALM, et al. Beyond the cardiorenal anaemia syndrome: recognizing the role of iron deficiency. Eur J Heart Fail. 2012; 14(8): 882-886, doi: 10.1093/eurjhf/hfs056, indexed in Pubmed: 22523375.

20. Anand IS. Pathogenesis of anemia in cardiorenal disease. Rev Cardiovasc Med. 2005; 6 Suppl 3: S13-S21, indexed in Pubmed: 16340934.

21. Weiss G, Goodnough LT. Anemia of chronic disease. N Engl J Med. 2005; 352(10): 1011-1023, doi: 10.1056/NEJMra041809, indexed in Pubmed: 15758012.

22. Lindenfeld J. Prevalence of anemia and effects on mortality in patients with heart failure. American Heart Journal. 2005; 149(3): 391-401, doi: 10.1016/j.ahj.2004.08.039.

23. Chełstowska M, Warzocha K. Clinical symptoms and laboratory changes in differential diagnosis. Onkologia w Praktyce Klinicznej. 2006; Tom 2, nr. ; 3: 101-116.

24. Jankowska EA, von Haehling S, Anker SD, et al. Iron deficiency and heart failure: diagnostic dilemmas and therapeutic perspectives. Eur Heart J. 2013; 34(11): 816-829, doi: 10.1093/eurheartj/ehs224, indexed in Pubmed: 23100285.

25. Anand IS. Pathophysiology of anemia in heart failure. Heart Fail Clin. 2010; 6(3): 279-288, doi: 10.1016/j.hfc.2010.03.002, indexed in Pubmed: 20630402.

26. Anand IS. Anemia and chronic heart failure implications and treatment options. J Am Coll Cardiol. 2008; 52(7): 501-511, doi: 10.1016/j. jacc.2008.04.044, indexed in Pubmed: 18687241.

27. van Veldhuisen DJ, Anker SD, Ponikowski P, et al. Anemia and iron deficiency in heart failure: mechanisms and therapeutic approaches. Nat 
Rev Cardiol. 2011; 8(9): 485-493, doi: 10.1038/nrcardio.2011.77, indexed in Pubmed: 21629210.

28. Jankowska EA, Rozentryt P, Witkowska A, et al. Iron deficiency: an ominous sign in patients with systolic chronic heart failure. Eur Heart J. 2010; 31(15): 1872-1880, doi: 10.1093/eurheartj/ehq158, indexed in Pubmed: 20570952.

29. Lewis GD, Malhotra R, Hernandez AF, et al. NHLBI Heart Failure Clinical Research Network. Effect of Oral Iron Repletion on Exercise Capacity in Patients With Heart Failure With Reduced Ejection Fraction and Iron Deficiency: The IRONOUT HF Randomized Clinical Trial. JAMA. 2017; 317(19): 1958-1966, doi: 10.1001/jama.2017.5427, indexed in Pubmed: 28510680.

30. Anand I, McMurray JJV, Whitmore J, et al. Anemia and its relationship to clinical outcome in heart failure. Circulation. 2004; 110(2): 149-154, doi: 10.1161/01.CIR.0000134279.79571.73, indexed in Pubmed: 15210591.

31. Groenveld HF, Januzzi JL, Damman K, et al. Anemia and mortality in heart failure patients a systematic review and meta-analysis. J Am Coll Cardiol. 2008; 52(10): 818-827, doi: 10.1016/j.jacc.2008.04.061, indexed in Pubmed: 18755344.

32. Felker GM, Gattis WA, Leimberger JD, et al. Usefulness of anemia as a predictor of death and rehospitalization in patients with decompensated heart failure. Am J Cardiol. 2003; 92(5): 625-628, indexed in Pubmed: 12943893.

33. Beck-da-Silva L, Piardi D, Soder S, et al. IRON-HF study: a randomized trial to assess the effects of iron in heart failure patients with anemia. Int J Cardiol. 2013; 168(4): 3439-3442, doi: 10.1016/j. ijcard.2013.04.181, indexed in Pubmed: 23680589.

34. Gutzwiller FS, Pfeil AM, Comin-Colet J, et al. Determinants of quality of life of patients with heart failure and iron deficiency treated with ferric carboxymaltose: FAIR-HF sub-analysis. Int J Cardiol. 2013; 168(4): 3878-3883, doi: 10.1016/j.jicard.2013.06.045, indexed in Pubmed: 23870642.

35. Ponikowski P, van Veldhuisen DJ, Comin-Colet J, et al. CONFIRM-HF Investigators. Beneficial effects of long-term intravenous iron therapy with ferric carboxymaltose in patients with symptomatic heart failure and iron deficiencyt. Eur Heart J. 2015; 36(11): 657-668, doi: 10.1093/eurheartj/ehu385, indexed in Pubmed: 25176939.

36. Maeder MT, Khammy 0, dos Remedios C, et al. Myocardial and systemic iron depletion in heart failure implications for anemia accompanying heart failure. J Am Coll Cardiol. 2011; 58(5): 474-480, doi: 10.1016/j.jacc.2011.01.059, indexed in Pubmed: 21777743.

37. Murphy MF, Wallington TB, Kelsey P, et al. Guidelines for the clinical use of red cell transfusions. Br J Haematol. 2001; 113: 24.

38. Muñoz M, Breymann C, García-Erce JA, et al. Efficacy and safety of intravenous iron therapy as an alternative/adjunct to allogeneic blood transfusion. Vox Sang. 2008; 94(3): 172-183, doi: 10.1111/j.14230410.2007.01014.x, indexed in Pubmed: 18069918.

39. Swedberg K, McMurray JJV, Young JB, et al. RED-HF Committees, RED-HF Investigators. Treatment of anemia with darbepoetin alfa in systolic heart failure. N Engl J Med. 2013; 368(13): 1210-1219, doi: 10.1056/NEJMoa1214865, indexed in Pubmed: 23473338. 